\title{
Iconographie et politique roumaine post- totalitaire : le cas de la télévision
}

\section{Râzvan Theodorescu}

\section{(2) OpenEdition}

Journals

Édition électronique

URL : http://journals.openedition.org/etudesbalkaniques/444

ISSN : 2102-5525

\section{Éditeur}

Association Pierre Belon

\section{Édition imprimée}

Date de publication : 1 janvier 2001

Pagination : 161-172

ISBN : 2-910860-10-8

ISSN : $1260-2116$

\section{Référence électronique}

Râzvan Theodorescu, « Iconographie et politique roumaine post-totalitaire : le cas de la télévision », Études balkaniques [En ligne], 8 | 2001, mis en ligne le 08 avril 2009, consulté le 04 mai 2019. URL http://journals.openedition.org/etudesbalkaniques/444

Ce document a été généré automatiquement le 4 mai 2019.

Tous droits réservés 


\section{Iconographie et politique roumaine post-totalitaire : le cas de la télévision}

Râzvan Theodorescu

AUTEUR

RÂZVAN THEODORESCU

Académie des Sciences, Bucarest 